\title{
Survey of Marine Phytoplankton in Ship's Ballast Tanks at Laem Chabang International Port, Thailand
}

\author{
Sumana Kajonwattanakul1 ${ }^{1,}$, Waranya Numnual ${ }^{1}$, Thanyapas Sirichaiseth ${ }^{1}$, and Tanet Wannarangsri ${ }^{1}$ \\ ${ }^{1}$ Marine and Coastal Resources Research and Development Institute, Department of Marine and Coastal Resources, Bangkok, \\ Thailand \\ ${ }^{*}$ Corresponding author: sumana11th@yahoo.com
}

KEYWORDS

Ship ballast water

Marine phytoplankton

\begin{abstract}
Marine phytoplankton was investigated in ballast water of ships from 2010 to 2012 with a collection of 30 marine vessels that docked at Laem Chabang International Port in Chonburi Province, Thailand. The results showed that the dominant group of phytoplankton was diatoms. The amount of phytoplankton in the ballast tanks averaged less than 10 cells $/ \mathrm{mL}$, which is less than Regulation D-2 of the Ballast Water Management Convention which requires that marine organisms between the sizes of $10 \leq X<50 \mu \mathrm{m}$ should be less than 10 cells $/ \mathrm{mL}$ and size $\geq 50 \mu \mathrm{m}$ should be less than $10 \mathrm{cell} / \mathrm{m}^{3}$ in ballast water. Alien species of phytoplankton was not recorded in this survey.
\end{abstract}

(c) The Author(s) 2018. This article is distributed under a Creative Commons Attribution-ShareAlike 4.0 International license.

\section{INTRODUCTION}

Nowadays, overseas shipping has been increasing due to lower transportation costs than other means. However, managing the security of maritime transport is not as efficient as they should be, particularly for environment safety. The transport of ballast water seems to play a key role in posing serious ecological, economic and health problems, due to the multitude of marine species that can be carried in modern ships which are both large and fast. Pioneering research carried out by Medcof (1975) and Carlton (1985) have shown that a large variety of animals, ranging from protists to fish, are able to survive as blind passengers in ballast water tanks for several weeks during transoceanic cruises. The transferred species may survive to establish a reproductive population in the host environment, becoming invasive, out-competing native species and multiplying into pest proportions. The spread of invasive species is now recognized as one of the greatest threats to the ecological and economic well being of the planet. Some of these species are causing enormous damage to biodiversity and the valuable natural riches of the earth upon which we depend for our survival. Direct and indirect health effects are also becoming increasingly serious and the damage to environment is often irreversible (IMO 2014). The International Maritime Organization (IMO) has formulated special regulations for reducing the transport of organisms, one of which is the exchange of water in the open ocean (IMO 1995). In 2004, the International Convention for the Control and Management of Ships' Ballast Water and Sediments (BWM Convention) was adopted (IMO 2009). Reduction of marine species in ballast water tanks was achieved by $100 \%$ empty-refill ballast water exchange (Ruiz et al. 2005).

Due to the lack of biological information concerning marine native and alien species, an adequate risk assessment is often elusive for many tropical countries. Relev- ant laws and regulations may be non-existent or require extensive review. In Thailand, the Marine Department at the Ministry of Transport (IMO national focal point for Thailand) has developed a "Road Map" and a "National Action Plan" on ship's ballast water management in recognition of the problems and impacts of invasive species transported via ship's ballast water to the marine environment. Research on marine invasive species has centred on the assessment of non-indigenous species possibly introduced by ballast water discharge (Carlton and Geller 1993). Meanwhile, Department of Marine and Coastal Resources have been working on this issue by conducting a survey of the marine phytoplankton in ship's ballast tanks to investigate diversity and density of phytoplankton, including the identification of possible alien species. Here we provide observations of phytoplankton found in ballast water carried out over two years between 2010 and 2012 from vessels de-ballasting at the port of Laem Chabang in the Gulf of Thailand.

\section{MATERIALS AND METHODS}

Ballast water samples were collected during 2010-2012 from 30 container vessels that docked at Laem Chabang Port. Water samples at a control station in the port area were also collected. This port is the main deep sea port of Thailand covering an area of about 1,040 ha located in Chonburi Province (Figure 1).

A total of $100 \mathrm{~L}$ of ballast water were sampled through an open manhole with a bucket or by an electrical pump. Salinity, $\mathrm{pH}$ and temperature of the samples were also noted.

Water samples were filtered through plankton nets with a conical diameter of $30 \mathrm{~cm}$ and a mesh size of $16 \mathrm{mi}^{-}$ crometers. Phytoplankton was preserved in Lugol's solution and counted under a compound microscope with maximum magnification of x100 with a compound 


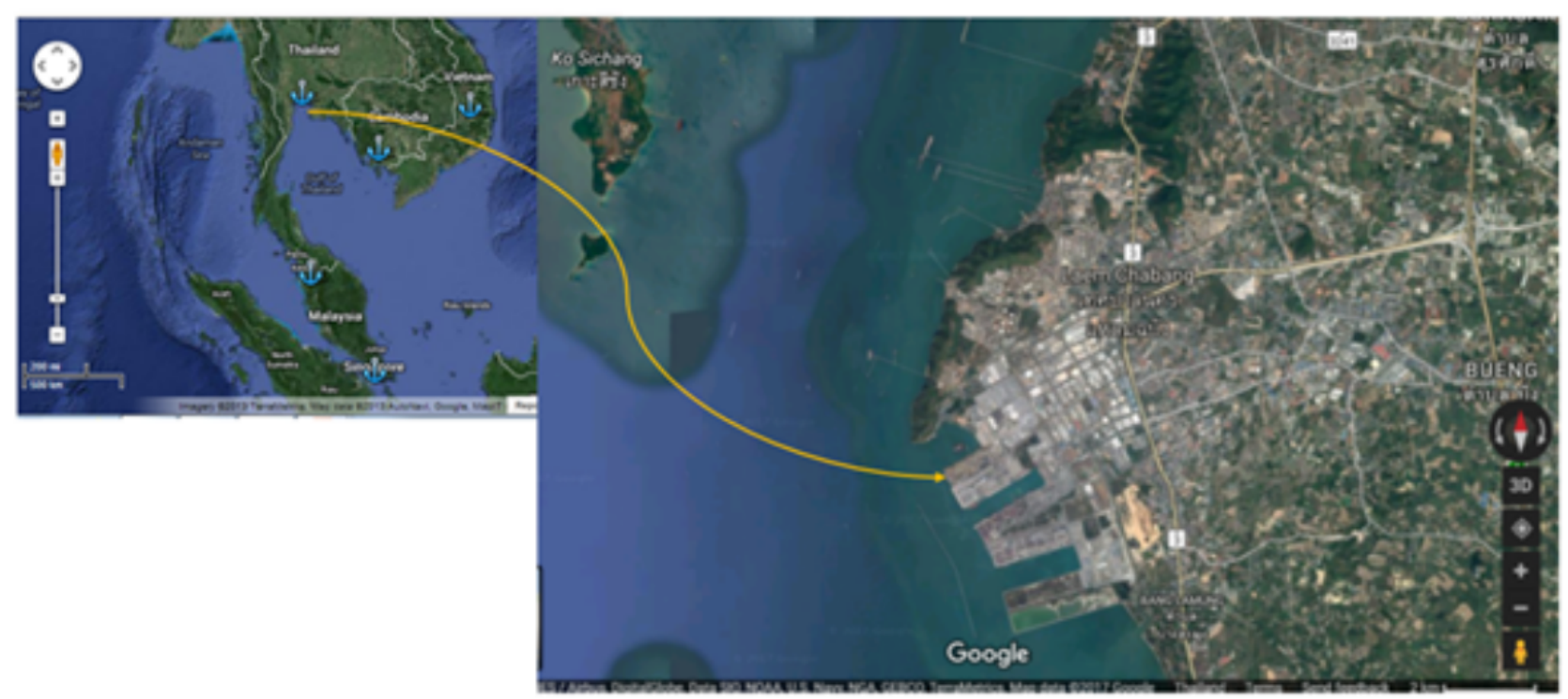

Figure 1. Location and layout of Laem Chabang Port in the Gulf of Thailand.

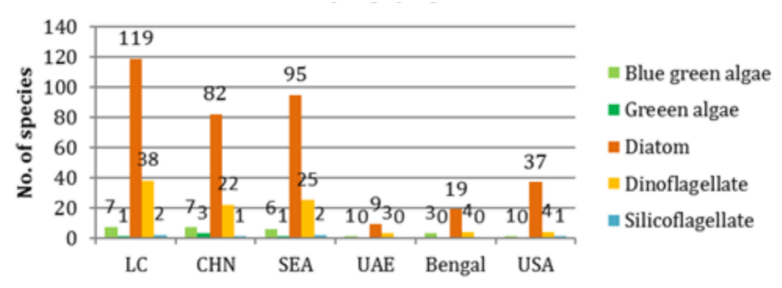

Figure 2. Diversity of phytoplankton in ship's ballast water surveyed at Laem Chabang Port based on 30 vessels.

Sedgewick-Rafter counting cell (Wongratana and Boonyapiwat 2003). Species identification was made according to Smith (1977), Fukuyo et al. (1990), Tomas (1996) and Wongratana (2001). Some phytoplankton was taken to identify by using Scanning Electron Microscope (SEM) model JSM 5200, JEOL.

The statistical package MVSP (Multi-Variate Statistical Package) version 3.1 was used to perform statistical analyses using UPGMA similarity matrices and Shannon's diversity indices.

\section{RESULTS}

During this survey ballast water samples were collected from 30 vessels (total 30 samples) and from control stations (total 34 samples). All ship routes were within Asia such as China, Hong Kong, Taiwan, South Korea, Vietnam, Thailand, Malaysia, Singapore and Indonesia. However, three of them had taken ballast water in previous trips from United Arab Emirates, Bay of Bengal and United State of America and duration of each cruise from origin to Thailand was about one week. Therefore, we have classified ship's ballast water from five original sources: 1) China (CHN); 2) South East Asia (SEA); 3) United Arab
Emirates (UAE); 4) Bay of Bengal; 5) United States of America (USA). These were compared with 6) control stations at Laem Chabang (LC).

\subsection{Environmental conditions}

The environmental conditions of ballast water sources are shown in Table 1. Salinity and $\mathrm{pH}$ of seawater from UAE were markedly higher than others at $44 \mathrm{PSU}$ and 9.0, respectively. In contrast, the salinity of samples from the Bay of Bengal was lowest at 5 PSU.

\subsection{Diversity and density of phytoplankton}

As a result of the studies conducted in ship's ballast water tank and control station at Laem Chabang Port, between 13 and 129 species of phytoplankton were recorded from ballast tanks whereas 167 species were observed at the control station. The phytoplankton comprised diatoms, dinoflagellates, green algae, blue green algae and silicoflagellates. Diatoms were the most diverse. The diversity of phytoplankton from six original sources is shown in Figure 2 and the density of phytoplankton is shown in Figure 3.

Phytoplankton in Laem Chabang Port waters had an average density ranging from $5.07 \times 10^{4}$ to $1.45 \times 10^{5}$ cells $/$ L. Diatoms were the dominant group with the highest density of $5.13 \times 10^{4}$ cells $/ \mathrm{L}$. They were followed by dinoflagellates, blue green algae, green algae and silicoflagellates, with densities of $3.29 \times 10^{4}, 5.12 \times 10^{3}, 80$ and 9 cells/L, respectively (Figure 4A). Diversity indices of 2013 samples were highest at 2.041 with 98 species. Dominant species were Ceratium furca, Chaetoceros curvisetus and C. pseudocurvisetus. In addition, a bloom of C. furca was observed in September 2010 reaching $9.68 \times 10^{4}$ cells/L in this area.

Ballast water samples originating from China were collected from 14 container vessels where ballast water

Table 1. Characteristics of ballast water from different origins. LC: Laem Chabang; CHN: China; SEA: Southeast Asia; UAE: United Arab Emirates; USA: United States of America.

\begin{tabular}{|c|c|c|c|c|c|}
\hline Origin of ballast water & No. of water samples & Age of ballast water (days) & Temperature $\left({ }^{\circ} \mathrm{C}\right)$ & Salinity (PSU) & $\mathrm{pH}$ \\
\hline LC & 34 & & $25.0-34.0$ & $22-34$ & 7.6-8.7 \\
\hline $\mathrm{CHN}$ & 28 & $2-4$ & $26.0-35.0$ & $15-34$ & $7.7-8.5$ \\
\hline SEA & 26 & $1-5$ & $26.0-33.0$ & $5-34$ & $6.9-8.9$ \\
\hline UAE & 2 & ND & 34.7 & 44 & 9.0 \\
\hline Bay of Bengal & 2 & ND & 34.9 & 5 & 7.9 \\
\hline USA & 2 & ND & 30.8 & 36 & 7.8 \\
\hline
\end{tabular}




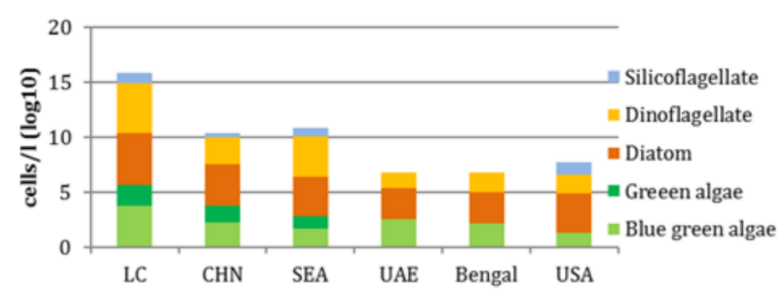

Figure 3. Density and composition of phytoplankton in ballast water of ships at Laem Chabang Port originating from different countries. LC: Laem Chabang, Thailand; CHN: China; SEA: Southeast Asia; UAE: United Arab Emirates; USA: United States of America.

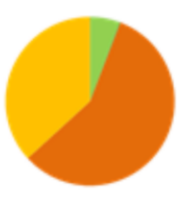

(A)

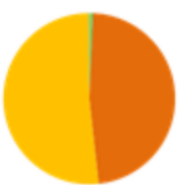

(B)

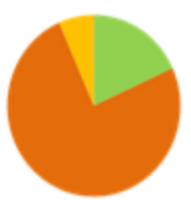

(C)

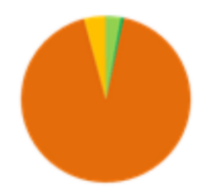

(D)

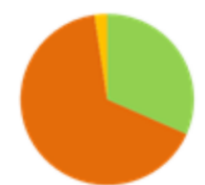

(E)

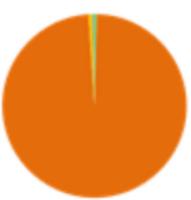

(F)
Figure 4. Density and composition of phytoplankton in port and ballast water. (A) Laem Chabang Port waters; (B) ballast water in vessel from China; (C) ballast water in vessels from Vietnam, Thailand, Malaysia, Singapore and Indonesia (pooled results); (D) ballast water from vessel originating in UAE (United Arab Emirates); (E) ballast water in vessel from Bay of Bengal; (F) ballast water in vessel from USA.

was transferred from South Korea, China, Hong Kong and Taiwan. Diversity of phytoplankton in this route was 115 species. Diatoms were the most diverse at 82 species with a density of $5.62 \times 10^{3}$ cells/L. This was followed by dinoflagellates, blue green algae, green algae and silicoflagellates with densities of $2.50 \times 10^{2}, 1.74 \times 10^{2}, 35$ and 3 cells/L, respectively (Figure 4B). Densities of phytoplankton ranged from 0 to $4.26 \times 10^{4}$ cells/L. Dominant species were Chaetoceros curvisetus, Thalassionema nitzchioides and C. pseudocurvisetus. Phytoplankton density in samples of ballast water from ships that originated from Chiwan (Shenzhen) and Ningbo (Shanghai) in China was higher than $1.0 \times 10^{4}$ cells/L. Diversity indices of ballast water samples from the two ships were 2.351 and 2.884 with 59 species, respectively.

Ballast water samples were also taken from ships originating in Vietnam, Thailand, Malaysia, Singapore and Indonesia. Total diversity of phytoplankton was 129 species. Diatoms were the most diverse comprising 95 species, while dinoflagellates was highest density. Density of phytoplankton ranged between 4 to $6.22 \times 10^{4}$ cells/L, with diatoms at $4.13 \times 10^{3}$ cells $/ \mathrm{L}$, dinoflagellates $4.49 \times 10^{3}$ cells $/ \mathrm{L}$, blue green algae 50 cells/L, green algae 12 cells/L and silicoflagellates 6 cells/L (Figure 4C). Dominant species were C. furca, Skeletonema costatum and C. pseudocurvisetus. In the most part the dominant species was C. furca with a typical density of about $5.67 \times 10^{4}$ cells/L. Three samples of ballast water were from Port Klang, Malaysia.
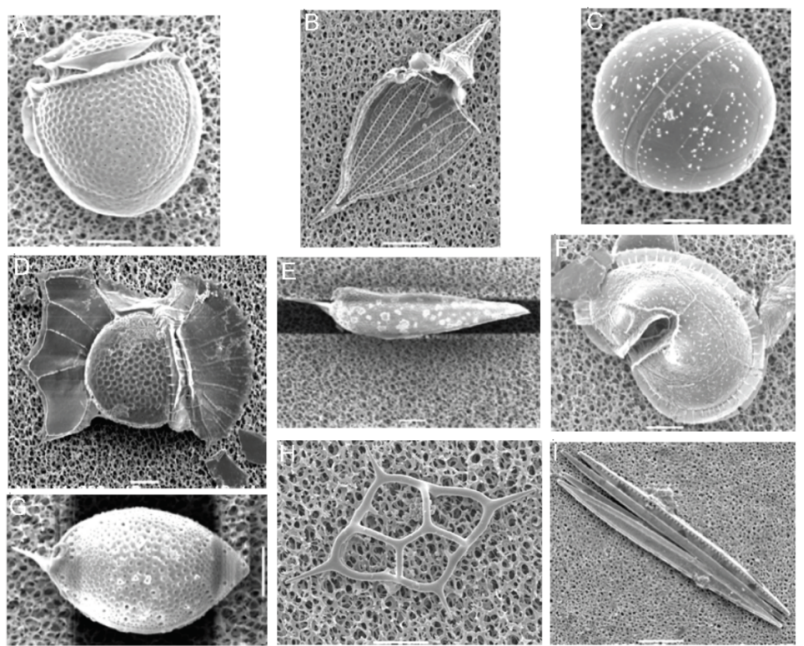

Figure 5. Representative phytoplankton in ballast water samples observed at Laem Chabang Port, Thailand. (A) dinoflagellate, Phalacoma sp.; (B) dinoflagellate, Oxytosum sp.; (C) dinoflagellate, Diplopsalis sp;. (D) dinoflagellate, Ornithocercus heteroporus; (e) dinoflagellate, Prorocentrum sigmoides; (F) dinoflagellate, Protoperidinium sp. (G) dinoflagellate, $P$. micans; (H) silicoflagellate, Dictyocha fibula; (I) diatom, Nitzschia sp. Scale bars: a-h, $10 \mu \mathrm{m}$; i, $20 \mu \mathrm{m}$.

Those from Surabaya, Indonesia and Singapore had phytoplankton densities higher than $10^{4}$ cells/L, and a sample from Port Klang, Malaysia reached $6.22 \times 10^{4}$ cells/L with the highest diversity index of 3.160 ( 55 species).

One of container vessel from Singapore had taken ballast water in the UAE. Diversity of phytoplankton was lowest at only 13 species with some nine species of diatoms. Diversity index was 2.095. Density of phytoplankton was $1.05 \times 10^{3}$ cells/L, comprising diatoms, dinoflagellates and blue green algae with densities of $6.95 \times 10^{2}, 25$ and $3.33 \times$ $10^{2}$ cells/L, respectively (Figure 4D). Dominant species were Trichodesmium spp., S. costatum and C. lorenzianus.

Ballast water sample originating from the Bay of Bengal was transferred by container vessel from Singapore. Phytoplankton density was rather low at 26 species with a diversity index of 2.619. Diatoms were the most diverse at 19 species. Density of phytoplankton was $6.35 \mathrm{x}$ $10^{2}$ cells/L, composed of diatoms, dinoflagellates and blue green algae whose densities were $6.28 \times 10^{2}, 55$ and $1.52 \times 10^{2}$ cells/L, respectively (Figure 4E). Dominant species were Pseudo-nitzchia spp., Thalassionema frauenfeldii and Oscillatoria erythraea.

Lastly, a ballast water sample was taken from a container vessel which had taken in ballast from U.S.A, whose last port of call was in China before arriving in Laem Chabang Port. This sample contained diatoms, dinoflagellates, blue green algae and silicoflagellates, whose densities were $3.38 \times 10^{3}, 47,18$ and 13 cells/L, respectively (Figure 4F). Diatoms were the most diverse at 37 species and it was by far the most dominant group comprising mainly S. costatum, Pseudo-nitzchia spp., and Thalassiosira spp. Among these S. costatum was the main component with a density of 4.38 $\mathrm{x} 10^{3}$ cells/L. Diversity index was rather low at 1.488 .

Among these 129 species of phytoplankton observed in ballast water, no alien species was observed. Representative phytoplankton from ballast water samples arriving at Laem Chabang Port are shown in Figure 5.

\subsection{Similarity of phytoplankton composition}

Cluster analysis in term of similarity of all ballast sources were performed and compared with Laem Chabang Port. The results are shown below. 


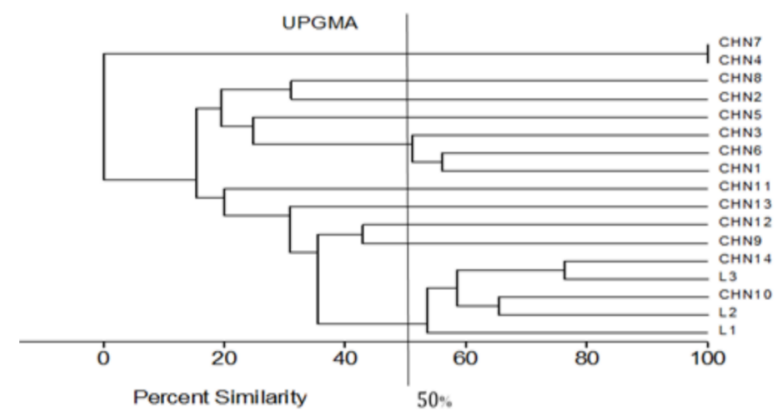

Figure 6. Percentage similarity between species composition of phytoplankton in Laem Chabang Port and China.

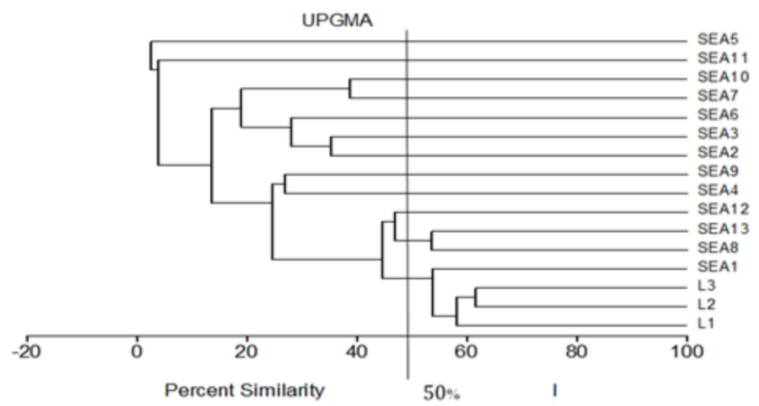

Figure 7. Percentage similarity between species composition of phytoplankton in Laem Chabang Port (L1-3) and Southeast Asia (SEA) region.

Figure 6 shows the percentage similarity between species composition of phytoplankton in Laem Chabang Port and China. First group is $100 \%$ similarity, comprised two vessels that originated from Chiwan in China (CHN4, CHN7). The second group with 53\% similarity comprised another two vessels that originated from Ningbo (CHN14) and Chiwan (CHN10) in China and Laem Chabang Port (L3). Last group is $51 \%$ similarity which comprised three vessels from Hong Kong, Shanghai and Kaohsiung, Taiwan (CHN1, CHN6 and CHN3).

Similarity between Laem Chabang Port and Southeast Asia region are shown in Figure 7 . There are two main clusters. One cluster (at 53\% similarity) comprised of one ship from Surabaya in Indonesia (SEA1) and three from Laem Chabang (L1-3). The other cluster at $47 \%$ similarity consisted of three ships from Dung Quat in Vietnam, Port Klang in Malaysia and Gulf of Thailand (SEA 8, 12 and 13).

The results of cluster analysis between Laem Chabang Port, United Arab Emirates, Bay of Bengal and United State of America are shown in Figure 8. There was only one cluster at $44 \%$ similarity, consisting of Laem Chabang (L1-3) and U.S.A.

\section{DISCUSSION}

Temperature and salinity, as well as $\mathrm{pH}$ of seawater in ballast tanks were regarded as environmental conditions affecting ballast water organisms. However, this study shows that salinity and abundance of phytoplankton in ballast tank was not related. Duration of cruise and darkness in the tanks may have affected by preventing photosynthesis of phytoplankton (Carlton 1985).

Duration of each cruise from last port to Laem Chabang Port was three to nine days. Otherwise ballast water samples were one to five days old, except UAE, Bay of Bengal and U.S.A. for which no data were available. In all these studies, a large number and variety of phytoplankton

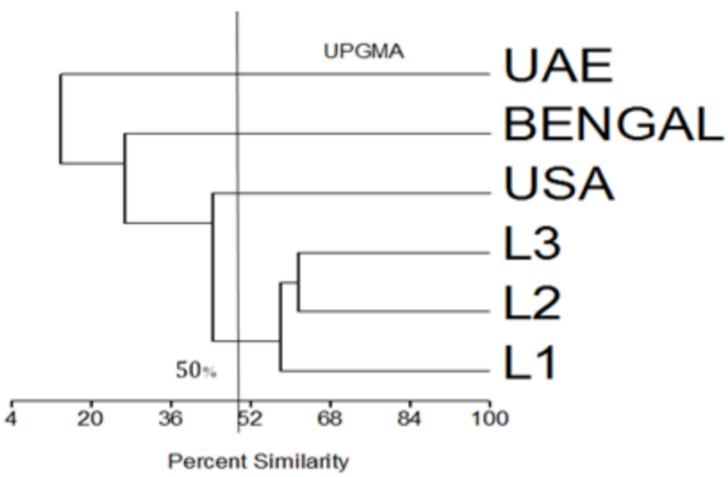

Figure 8. Percentage similarity between species composition of phytoplankton in Laem Chabang Port, and ballast water received from United Arab Emirates, Bay of Bengal and United States of America.

was recorded in ballast water tanks, and diatoms were the most diverse group. However, there are only few reports on survival rate and the fate of ballast water organisms during their transport (Fukuyo et al. 1995; Hallegraeff 1998). Gollasch et al. (2000) observed the survival of tropical ballast water organisms during 23 days voyage from Singapore to Germany. The results showed that the freshly sampled ballast water contained about 1 cell/L, representing a very low concentration of larger phytoplankton species $(>10 \mu \mathrm{m})$, most of which were diatoms. The sample consisted of 30 diatom species. Their abundance dropped rapidly within the first 10 days and remained at a very low level until the end of the cruise. The very few dinoflagellates disappeared in the same period. In comparison, our study in Laem Chabang Port showed that the density of phytoplankton in ballast water samples were much higher, excluding two samples of Southeast Asia and three samples of China that contained lower than 100 cells/L. Diversity was also high except those from UAE and Bay of Bengal where the diversity was low (13 and 26 species respectively). Nevertheless, duration of transferred ballast water from UAE, Bay of Bengal and U.S.A. was probably longer than 10 days were either high density, particularly U.S.A. samples when compared with Gollasch et al. (2000).

Dinoflagellates were found, including the potentially harmful genera Dinophysis, Gonyaulax, Alexandrium and Prorocentrum in ballast samples originating from China and Southeast Asia while UAE and Bay of Bengal had presented only Prorocentrum. Alexandrium catenella was reported as the 100 worst invasive species' in the Mediterranean Sea, with significant impacts on socio-economy in terms of fisheries and health (Streftaris and Zenetos 2006), whereas P. minimum is classified as an alien invasive species in the Baltic Sea (Olenina et al. 2010).

The average diversity of phytoplankton in each origin of ballast water was less than 10 cells $/ \mathrm{mL}$. Otherwise, $14.3 \%$ of samples from China and $23.1 \%$ of southeast Asia sampled were higher than 10 cells/mL that exceed the requirement of Regulation D-2 of BWM convention.

Our investigation could not determine the noticeable similarity of phytoplankton composition in each original source of ballast water. The difference between seasonal and environmental conditions may have affected the initial composition of phytoplankton.

\section{ACKNOWLEDGEMENTS}

We are grateful to the Port Authority of Thailand for permission to undertake field sampling and their support throughout the sampling period. We would like to thank 
Assist. Prof. Sunan Patarajinda, Kasetsart University for assistance on systematic sampling and phytoplankton identification. We thank the staff of the Marine and Coastal Resources Research and Development Institute for their dedication to this survey. This study was supported by the ASEAN-India Cooperation Fund. We thank the reviewers whose suggestions improved the manuscript.

\section{REFERENCES}

Carlton JT. 1985. Transoceanic and interoceanic dispersal of coastal marine organisms: the biology of ballast water. Oceanography and Marine Biology Annual Review 23:313-371.

Carlton JT, Geller JB. 1993. Ecological roulette: the global transport of non-indigenous marine organisms. Science 261:78-82.

Fukuyo Y, Takano H, Chihara M, Matsuoka K. 1990. Red tide organisms in Japan - an illustrated taxonomic guide. Tokyo: Uchida Rokakoho.

Fukuyo Y, Ikegami T, Murase T. 1995. Unwanted aquatic organisms in ballast tank. Report of the ballast water treatment by using main engine water cooling circuit and findings of the on-board research. ICES Annual Science Conference; 1995 Sep 21-29; Aalborg, Denmark. p. 1-12.

Gollasch S, Lenz J, Dammer M, Andres HG. 2000. Survival of tropical ballast water organisms during a cruise from the Indian Ocean to the North Sea. Journal of Plankton Research 22:923-937.

Hallegraeff GM. 1998. Transport of toxic dinoflagellates via ship's ballast water: bioeconomic risk assessment and efficacy of ballast water management strategies. Marine Ecology Progress Series 168:297-309.

[IMO] International Maritime Organisation. 1995. Unwanted aquatic organisms in ballast water. Proposed draft regulations for the control and management of ship's ballast water to minimize the transfer of harmful aquatic organisms and pathogens. London: International Maritime Organisation. p. 1-9.

[IMO] International Maritime Organisation. 2009. Ballast water management convention and the guidelines for its implementation. London: International Maritime Organisation. p. 234.

[IMO] International Maritime Organisation. 2014. Ballast water management. London: International Maritime Organisation; [accessed 2014 Sep 2]. http://www.imo.org/en /ourwork/environment/ballastwatermanagement/pages/default.aspx.

Medcof JC. 1975. Living marine animals in a ship's ballast water. Proceedings of the National Shellfish Association 65:54-55.

Olenina I, Wasmund N, Hajdu S, Jurgensone I, Gromisz S, Kownacka J, Toming K, Vaiciute D, Olenin S. 2010. Assessing impacts of invasive phytoplankton: the Baltic Sea case. Marine Pollution Bulletin 60:1691-1700.

Ruiz GM, Murphy KR, Verling E, Smith G, Chaves S, Hines AH. 2005. Ballast water exchange: efficacy of treating ships' ballast water to reduce marine species transfers and invasion success? Edgewater: Smithsonian Environmental Research Center. p. 1-17.

Smith DL. 1977. A guide to marine coastal plankton and marine invertebrate larvae. Dubuque: Kendall/Hunt Publishing Company.

Tomas CR. 1996. Identifying marine diatoms and dinoflagellates. San Diego: Academic Press.

Streftaris N, Zenetos A. 2006. Alien marine species in the Mediterranean - the 100 'worst invasives' and their impact. Mediterranean Marine Science 7(1):87-188.

Wongratana L. 2001. Phytoplankton. $2^{\text {nd }}$ ed. Bangkok: Kasetsart University Publisher.

Wongratana L, Boonyapiwat S. 2003. Guideline for collected and identified plankton. Bangkok: Kasetsart University Publisher. 
